\title{
Literature Review on Educational Attainment of Migrant Children in China
}

\author{
Huafeng Zhang \\ Fafo Research Institute, Oslo, Norway \\ Email: zhu@fafo.no
}

Received 10 June 2016; accepted 24 July 2016; published 27 July 2016

Copyright (C) 2016 by author and Scientific Research Publishing Inc.

This work is licensed under the Creative Commons Attribution International License (CC BY). http://creativecommons.org/licenses/by/4.0/

c) (i) Open Access

\begin{abstract}
This paper reviews the literature on migrant children's educational attainment in Chinese urban cities. The review attempts to explore the central government's policy of institutional segregation and the barriers established by local policy on the issue of migrant children's access to education. Furthermore, the review examines the direct consequences of policies that limit migrant children's school enrollment, thus affecting their educational and psychological performance and their social integration in urban areas. Lack of equal access to education for migrant children is also closely correlated with education inequality and poverty, which reinforce each other and form a trap for poor families. Finally, this paper endeavors to review the contribution of recent studies on migrant children's education in urban cities, with a focus on quantitative data and methods applied by recent studies on the topic. At the same time, the review discusses the limitations of current studies and potential areas for future research.
\end{abstract}

\section{Keywords}

Migrant Children, Educational Attainment, Education Inequality, Poverty, Quantitative Method

\section{Introduction}

In the past four decades, China has witnessed massive population movement from rural areas to urban areas and from small cities to big cities. What makes Chinese internal migration to be the focus of scholars' attention is its peculiar household registration system (hukou system), which, based on where one is registered, endows different segments of the population with different rights and different access to various social welfare programs and services [1]-[4].

The Chinese 2010 population census reported that 221.4 million people lived for more than six months outside the place where their hukou was registered [5]. This figure did not include those who moved within the 
same municipality or prefecture-level city. This was an 81.03 percent increase over the number in the 2000 census. Based on the same definition, the 2010 population census reported 22.9 million migrant children aged 0 to 14 and 13.9 million aged 6 - 14, who were at age for compulsory education. Large numbers of unmarried young internal migrants will bring even more migrant children into cities if they choose to settle down there.

Constrained by the household registration (hukou) system, migrants and their children, even if they live in a city for years, are still called "floating population" or "temporary migrants". They are excluded from the urban social welfare system, such as urban health insurance, unemployment benefits, urban public education, pensions, etc. In response to the social problems arising from institutional exclusion and social concerns, a series of government policies at both the central and local levels have been established in past two decades. Although these policies are aimed at reforming the hukou system and admitting migrant children to urban schools, the effectiveness of such reforms is controversial.

The literature on the hukou system and its consequences for the education of Chinese migrant children has grown since the 1990s and gains increasing attention since the early 2000s [6]-[10]. Studies in English on the educational attainment of migrant children did not appear until early 2000s [11]-[14]. The main concern of the early literature on migrant children was the direct consequences of government policies on migrant children's school enrollment. Recently, their educational and psychological performance, as well as their social integration in urban areas, has attracted more academic attention. Some researchers have begun to keep a closer eye on the correlation between migrant children's lack of equal access to education in urban cities and education inequality or poverty. The Chinese literature is, to a large extent, descriptive or qualitative research, and this review focuses mainly on the quantitative studies among the literature in English.

The remainder of the paper is organized as follows. Section 2 reviews the institutional background of the hukou system, central policies on providing equal rights to migrant children, and local policy implementation. The literature on various barriers to migrant children's access to education in urban cities is discussed in Section 3. Sections 4 and 5 explore current debates on the direct and indirect social consequences of the hukou system's constraints on migrant children's educational attainment. Section 6 reviews the quantitative survey data available for studying migrant children's education, together with the quantitative methods applied in the recent literature. Finally, Section 7 concludes with the limitations of current studies and the potential areas for future research work.

\section{Institutional Background: One Country, Two Identities}

\subsection{Household Registration System (Hukou) and Fiscal Decentralization}

The Chinese household registration system (hukou system) restricts population mobility and limits people's access to state-sponsored social benefits. The hukou system institutionalizes inequality and disadvantage for the rural hukou holders, and has been subject to much debate and scorn. Hukou has regulated Chinese internal population migration for almost 60 years [3]. More importantly, together with the widening rural-urban divide along China’s economic development [15], the hukou system has established hierarchies for income, housing, education, employment, retirement benefits, and medical and other services [3] [16] [17].

Although the hukou system's restrictions on population mobility have decreased since the economic reform, its role in differentiating between various populations' rights to public welfare and services has been reinforced [2] [18]. The central government no longer plays a key role in approving the officially sanctioned transfers of people's hukou registration. Instead of urban and rural divisions, the new hukou system focuses on distinguishing "locals" from "outsiders" (non-migrants from migrants), which is especially evident in their different abilities to access welfare and social benefits in urban areas [19].

The conditional, low-fee granting of an urban hukou in small urban towns are probably the only attempt to provide help to rural migrants in any real sense [4] [20]. While the small towns with few social benefits have a low threshold for hukou entry, the big cities with the most migrants set up the most demanding "entry conditions” [4]. Furthermore, the granting of an urban hukou, in many cases, requires the expropriation of land and, therefore, is not preferred by rural residents.

Fiscal decentralization reform since the 1980s has empowered local governments with more responsibility for distributing public spending [21]. Imbalanced urban-rural development differentiated local governments’ capacity to fund education and contributed to widening regional disparities in public education expenditures in China [22]-[26]. The already existing huge rural-urban disparity in educational provision has led to complicated issues 
for the children of rural migrant workers trying to access equal education in urban cities. Local urban governments are unwilling to spend their limited funds on migrants who don't have local hukou registration, while the huge gap between rural and urban education resources leaves little room for the rural governments where migrants have their hukou to supplement the funding deficit. The decentralized education-funding system makes the education of migrant children no one's responsibility.

\subsection{Central Educational Policies on Migrant Children's Equal Right to Education}

Recent literature on centralized legislation, regulations and administrative policies indicate a gradual change of the central government's educational policy for migrant children from exclusive to inclusive [27] [28].

The Compulsory Education Law (中华人民共和国义务教育法) adopted in 1986 stipulated that all children aged six, regardless of gender, ethnicity and race, should be enrolled in nine-year compulsory education in China. The earliest government policy documents on migrant children's right to compulsory education were not published until the mid-1990s. The Chinese National Education Committee and Public Security Department published “The trial measure of school education for school-age children among urban floating population” (《城 镇流动人口中适龄儿童、少年就学办法(试行)》) in 1996 [29] and “The interim measure of school education for migrant children” (《流动儿童少年就学暂行办法》) in 1998. However, the two measures imposed strict conditions on migrant children's enrollment in urban public schools and stipulated that both the governments of origin and destination must grant approval. Migrant children can get temporary places in public school only by paying extra school fees.

The state council published “The Decision of Basic Education Reform and Development” (《关于基础教育改 革与发展的决定》) in 2001 and “The Notice on the Management and Service for Rural Migrant Workers” (《关 于做好农民进城务工就业管理和服务工作的通知》) and “The Notice of Improving Education of Children of Rural Migrant Workers” (《关于进一步做好进城务工就业农民子女义务教育工作的意见》) in 2003. The 2003 notice emphasized the responsibility of local city governments provide equal education to migrant children without charging extra fees. The new Compulsory Education Law in 2006 stipulated that compulsory education should be free of tuition and incidental fees and that migrant children are entitled to "equal rights of education" in local areas. However, the specific measures guaranteeing migrant children's equal rights to education are up to the local governments of provinces and municipalities.

\section{Local Policy Implementation: Barriers to Migrant Children's Equal Rights to Education}

In spite of the central government's efforts to create policies that facilitate migrant children's access to education in urban cities, the large regional gap in educational resources discouraged local governments from adapting the central educational policies. Various financial and administrative barriers were established in urban cities that hinder migrant children's pursuit of education. There was a selective adaptation of local governments in complying with the central policy objective and principles [30].

A large number of studies over the past 15 years have reported different local financial and administrative barriers that have restricted migrant children's equal access to school in urban cities [1] [31] [32]. The substandard quality of migrant children's schools has aroused interest among scholars [13] [33] [34]. Finally, in many cities, migrant children without local hukou are not eligible to take entrance exam to schools after compulsory education, which prohibits them from continuing with higher education [35] [36].

\subsection{Financial and Administrative Barriers to Migrant Children’s Enrollment in Urban Public Schools}

The early studies on educational attainment for migrant children have focused on financial barriers to migrant children's access to the nine years of compulsory education. The 1998 measure formulated strict conditions and explicitly demanded the extra fees (Ze xiao fei, Jie du fei) from migrant families that wanted to enroll their children in urban public schools. The amount of these fees varied considerably across areas and by time and also depended to a great extent on the quality of public schools. [37] reports that migrant children were charged RMB 1200 a year for public primary school and RMB 2000 a year for junior high school in 2004. [32] reports that before 2004, there were two official government sets of fees for children without a residence permit: the 
“education compensation fee” of RMB 1000 a semester and the "temporary schooling fee” of RMB 680 a semester. Including other costs, the total annual fees could be more than RMB 8000 in Beijing. [13] reports the extra fees at prestigious public schools to have been over 10,000 RMB - and some as high as RMB 230,000-in Beijing. While the salary of the typical migrant worker was no more than RMB 500, the extra school fees for migrant children were far from affordable for migrant families and the main obstacle to their attendance.

The 2002 notice and the new education law emphasized free compulsory education to migrant children. In 2010, the Ministry of Education published “The decision on amending and repealing part of the regulations", which expressly stipulated the abolishment of extra fees charged by public schools. However, researchers continued to report from their field work that the extra fees charged by local public schools remained one of the main barriers to migrant children's educational attainment after 2004 [31] [32] [38].

\section{Administrative Barriers}

When the new central policies abolished extra fees on migrant children, various local administrative requirements replaced extra fees. Based on the hukou registration system, administrative barriers replaced financial barriers as the most important means for denying migrant children's rights to enter public schools. Migrants, who used to be able to simply pay to enroll their children in urban public schools, are now faced with even more difficult administrative restrictions. Some seemingly very positive signals that local governments were incorporating migrant children into local public schools were not as promising as they seemed.

Various versions of official documents are required for migrant children to enter public schools, both across and within provinces or even within a city [28]. After 2004, Beijing's government stipulated that migrant children must provide "five certificates" to be enrolled in public school without an extra fee. However, in reality, some urban schools demanded many more than five, even up to 28 certificates [39]. [32] lists eight certificates needed for migrant children to be enrolled in public school in Beijing after 2004, and [34] lists six certificates or documents required in Shenzhen. [35] cites five or six documents needed in Shanghai. At least four documents were the basic requirement for migrant children to be enrolled in urban schools in other cities, such as Lanzhou and Chengdu [28] [40].

The key documents demanded for enrolling migrant children in most large cities are documents of temporary residence, housing purchase or rental, and parents' employment. In many cases (such as in Shanghai), parents should have worked there for a certain period (between six months and two years) for their children be admitted to school [35] [41]. While many migrants work in unstable or seasonal low-paid jobs, it is not easy to buy or rent a house in places where such formal documents are required for school enrollment. In many cities, migrants must present additional documents and meet certain requirements to obtain temporary residences. There is little chance for many migrant families to provide all the documents needed for their children to be accepted in urban public schools. Urban cities' new administrative requirements regarding migrant children's education mean that public schools are, by no means, fully open to all migrant children. Rather, they are merely a way to incorporate the children of migrant families that have better resources.

The new point system for issuing migrants residence permits, launched by the Shanghai government in 2013, is another example of policy bias and represents a new form of discrimination against migrants[41] [42]. This system distributes points based on migrants' financial qualifications, profession and education [43]. The migrants who collect enough points are assigned Shanghai residence permits, allowing them to enjoy various welfare and social services to certain extent. Those who fail to pass the point test can be granted temporary residence permits, with much less access to social welfare than otherwise. However, even with temporary residence permits, only migrants with stable employment and housing contracts for at least six months can apply [44].

Many other big cities have introduced Shanghai’s point system-including Beijing, Tianjing, Shenzhen, and Guangzhou, most of which are ranked high in terms of GDP per capita. With the point system, city governments clearly show their preference for talent and capital, which are valuable to a city's economic growth. At the same time, the number of migrants that can benefit from the city’s development is still strictly controlled administratively by the local government. The wealthier the city is, the stricter the controls it tends to impose on local hukou acquisition for poor rural migrants [45].

Due to the Chinese fiscal decentralization policy, local governments have had considerable power to maneuver so as to accommodate their heterogeneous interests [46]. The local strategies and policies of various agencies, and even different levels within an agency, can vary to a large extent [13]. Various studies focus on different local regulations within particular time periods. However, none has performed a systematic study comparing and 
mapping the local regulations on migrant children's access to public education in cities.

\subsection{Unlicensed and Unregulated Migrant Schools with Low Quality}

Another branch of the literature investigates private migrant children's schools, which were initiated in the early to mid-1990s by migrants themselves to meet the urgent schooling needs of their children in urban cities. Although most of these schools were illegal, during the 1990s and early 2000s, local government took a general attitude of inaction (“Do not ban, do not recognize, let it run its course” 不取缔, 不承认, 自生自灭) towards private migrant schools [13].

The main concern in studies of private migrant schools is the low quality of education that they provide. Many qualitative studies present a picture of migrant schools characterized by poor facilities and low-quality teachers [13] [31] [32] [34] [38]. Some studies report the quality of migrant schools to be even worse than that of the rural public schools where migrants originally come from [34].

The migrant schools grew rapidly in the 1990s and early 2000s, with the number of new schools peaking in 1998 in Beijing [47]. Since 2006, many big cities, including Beijing, Shanghai, and Guangdong, have started to close down the low-quality migrant schools and tried to include migrant children in the public schools [48] [49]. In some cities, such as Beijing, since the public schools did not have capacity to accept all the migrant children, some were out of school or had to return to their home village. By 2007, some studies reported over 300 migrant schools enrolling 170,000 migrant children in Beijing [50] [51]. In 2011, although many migrant schools had been closed down, approximately 140,000 children were still reported as enrolled in migrant children's schools in Beijing [52].

Other cities, such as Shanghai, decided to invest in and register the migrant schools. In 2008, Shanghai's government launched a three-year plan to further open up public schools to migrant children and to subsidize migrant schools [53]. In 2007, Shanghai was reported to have 258 unregistered informal migrant schools; by the end of 2009, only 23 remained, and 151 had become registered state-subsidized private schools only for migrant children [35]. Among around half a million migrant students in Shanghai, about 70 percent were enrolled in public schools, while the rest studied in authorized migrant schools [33].

There are no reliable statistics on the number of migrant schools functioning legally or illegally, as well as the number of migrant children enrolled in these schools. The official reports or surveys on the number of migrant children excluded from public schools are underestimated, as, in many cases, only registered "temporary residents" are included, while many rural migrant parents employed on a temporary basis are ineligible to be registered [35].

\subsection{Barrier to High School and College Admission in Urban Cities}

Beyond mandatory education, the restriction on migrant children's access to education in urban cities is even worse. First, formal institutions do not acknowledge schooling in migrant schools; therefore, there is little chance for migrant children to continue on to higher-level education. Second, only children with local hukou can take the entrance exams for higher-level schools in the city. Due to the imbalance in regional development of higher institutions, city governments with better access to higher institutions are unwilling to give migrant children the same right of access to local entrance exams [54].

In 2010, the State Council published "Long-term Education Reform and Development Plan (2010-2020)" (《国家中长期教育改革与发展规划纲要 (2010-2020 年)》) [55]. The plan urged local governments to “study and formulate the regulations to admit migrant children to the entrance examination to tertiary education" (Gaokao). Even though 80,000 migrant children were reported to have taken the entrance exam in cities in 2015 [56], the state council's gaokao reform did not address hukou-related institutional barriers [54] [57]. In 2015, the regulation published by the Ministry of Education for the college entrance exam stipulated that "[i]n principle, all the students who apply for higher institutions should register for the entrance exam in the province where their hukou is registered" [58]. The only improvement in recent years was one additional provision added in 2010: "The Provincial admission committee can make specific supplementary regulations for those who have been enrolled in local school for certain years." Local registered hukou will continue to be the key prerequisite for children to be qualified for taking the higher-education entrance exam in cities.

Serious obstacles hinder migrant children's equal opportunity to higher education in urban China, including different school systems to which migrant children have to adapt when moving from their hometown to an urban 
city [59]; the expectation of difficulties in pursuing higher education in urban cities [36]; and the opportunity costs of higher education [60]. So far, relatively few empirical studies illustrate the effect of such restrictions on expanding the inequality of higher educational attainment, their potential adverse effect on migrant children's enthusiasm for compulsory education, and their effect on migrant children's long-term educational development.

\section{Direct Social Consequences: Migrant Children's Behavior and Educational Attainment}

The literature in the 1990s and early 2000s focused heavily on migrant children's low school enrollment rate. Since 2003, when more migrant children were admitted to urban schools, the quality of their education has attracted more attention. Studies have compared migrant children's academic performance not only between different schools, but also between local urban children and those from the original rural location. In addition, psychological adaptation to the urban life and the social integration of migrant children into urban schools are important aspects of recent studies. Migrant children's school enrollment, educational performance, psychological adaptation and school integration are all seen as direct effects of the dual hukou system on migrant children's educational attainment.

\subsection{Educational Attainment, School Enrollment}

The rate of migrant children not enrolled in school is exceptionally high in China. The national school enrollment rate was $99.7 \%$ in primary school and 98.3\% in junior high school in 2013 [5]. In contrast, the nine-city survey in 2003 showed that $9.3 \%$ of school-aged migrant children were out of school [61].

Most studies on migrant children's school enrollment find a rather worrisome situation for these children. Many scholars compare migrant children's school enrollment with that of children from their original rural areas and that of children in their destination urban areas. They discuss the determinants of migrant children's school enrollment at both the micro and the macro level. At the micro level, household characteristics, such as household composition, family size and economic conditions, are found to be important determinants. [11] reports that the parents' educational level and hukou type (agricultural/non-agricultural), their length of stay in the city, and whether migrant children live with their mother all affect children's school attendance. [62] finds that urban migrant children have a much worse schooling situation than either local urban or rural children. [63] indicates that hukou status plays a key role: temporary migrant children without local registration have a much worse educational situation than both non-migrant urban and rural children, while permanent migrant children with local hukou status fare even better than local urban children.

At the macro level, researchers compare migrant children's school enrollment in public schools across cities [1] [64]. On the one hand, large, coastal and wealthy cities have more restrictions on migration and are less willing to extend their social welfare programs to rural migrants. On the other hand, small and medium-sized cities provide migrant children with better access to urban public schools [1] [65].

[64] discusses the determinants of migrant children's schooling at both the micro level (child level and family level) and the macro-level (city level) with multiple measures of schooling. She finds that migrant children in developed cities are not only disadvantaged in school enrollment, but also have a greater chance of being sent to work.

\subsection{School Performance}

While school enrollment is about the quantity of migrant children admitted into school, school performance is about the quality of the education that migrant children receive. Most of the current literature evaluates migrant children's school performance by their academic scores.

Compared to urban local children, migrant children are reported to have much worse academic performance [31] [66]. One exception to this finding is in the study by [67], who compare a comprehensive list of outcomes, such as migrant children's educational performance, political knowledge, subjective well-being, inter-personal relationships, time use, and nutrition. The authors conclude that urban migrant children's performance is not worse than that of local urban children and that migrant children are doing better than rural children. At the same time, they conclude that children left behind by migrant parents do not perform worse than rural children 
in non-migrant families. However, based on the same survey data, a study of migrant children's nutrition, education quality and parents' parenting style concludes that migrant children do not perform significantly better than rural children and, in fact, lag far behind urban children [68].

Studies also address the controversial issue of migrant children's performance in informal migrant schools. Many studies share the consensus that school type is one of the most important determinants of migrant children's academic performance. [33] finds that several factors are highly correlated with school types, including students' academic test scores, parental assessment and satisfaction with school quality. Parents with children in public schools are much more satisfied than those with children in migrant schools. [69] finds that test scores of students in Beijing migrant schools were initially higher than those of children in Shaanxi rural public schools when they arrived in Beijing. However, children in migrant schools gradually lost ground to rural children due to poor school resources and teacher quality. This was not the case for migrant children in public schools. [70] indicates that the academic performance of migrant school children is, to a large extent, affected by factors such as school type, number of siblings, length of residence in urban areas, gender, preschool attendance, and parental socioeconomic status; on the contrary, parental socioeconomic status was the only significant factor affecting the academic performance of migrant children in public schools. [27] further confirms that after controlling for parental and family factors, migrant children in public schools perform equally well as local children.

Other studies emphasize the importance of the disadvantaged social background of migrant families, such as low involvement of migrant parents in children's schooling, instability, inconsistency of schooling due to parents' mobile status [38], and the suboptimal family environment for studying [31]. However, such studies are mostly anecdotal or descriptive and based mainly on small-scale qualitative interviews in small areas.

The type of schools that migrant children attend and the children's school performance can be both highly correlated with parents' social background. The factors are interwoven with and reinforce each other. Unfortunately, relatively few studies take such endogeneity into consideration when looking at the effects of school type on migrant children's school performance. [69] attempted to do so by incorporating migrant children's academic performance, student background, school quality and school type into their analysis. However, to compare the test scores of migrant school children in Beijing and rural public school children in Shaanxi is rather controversial due to the large differences between their educational systems. Furthermore, the diversified origins of migrant children in Beijing are also not taken into consideration in analysis. So far, there is little systematic research on the multiple correlations among the social background of migrant families, school type and migrant children's school performance.

\subsection{Psychological Well-Being}

Many studies explore the psychological and behavioral consequences of migration on migrant children. Children who migrate with their families meet challenges from a new social and cultural environment in cities. Even though they do not face the consequences of separating from their parents as left-behind children, they experience marginalization and discrimination by the urban social system, and they must struggle to integrate into an urban society that can be hostile to them. Studies find that migrant children suffer from symptoms of anxiety, depression and other identified risk factors associated with their psychological well-being [71].

Researchers explored the different impacts of two main types of schools in urban cities-migrant children's schools and public schools_on migrant children's psychological well-being. [72] indicates that while migrant children in urban public schools have improved psychological well-being over time, the feelings of loneliness and isolation among children in migrant schools does not completely fade away. [73] finds that public school attendance serves as a protective factor for migrant children's mental health. Mental health, measured as both externalizing problems and life satisfaction, is not significantly different between local children and migrant children attending public schools, while migrant children in migrant schools have much worse mental health than their cohorts. However, such studies do not consider the self-selection of migrant children with poor family backgrounds into migrant schools. Furthermore, the construction of psychological status indicators varies, and there is no standard of comparison for such studies.

While many studies explore the effects of migration on migrant children's psychology, others discuss the mechanisms that affect migrant children's psychological well-being. For example, by applying a hierarchical regression, [71] explores both the risk factors and the protective function of relationships and how they relate to migrant children's life satisfaction. Social support and self-esteem, as well as parent-child and peer relationships 
have been found to play an important role in improving the life satisfaction of migrant children in Shanghai [71]. [74] examine the effects of family migration, family environment and school characteristics on children's psychological and behavioral problems. Their study called for multi-level intervention strategies with respect to individual adjustment, family intervention, community support, school improvement and policy reform. [52] studies the positive role of maternal warmth and encouragement of sociability in migrant children's social and school achievement and psychological adjustment [52]. [75] offers two intervention strategies to improve migrant children's academic performance, to increase their identification with learning and to reduce the threat of stereotypes at school.

\subsection{Social Integration and School Segregation}

Social discrimination, the stigma of being migrants and school segregation are reported by some qualitative studies as important obstacles [31] [76]. Researchers find that migrant children, both in segregated migrant children's schools and in the public schools, suffer discrimination based on their low social status and rural origin. Such school interactions shape their identity, causing them to feel marginalized and embarrassed: they live in urban cities where they find it difficult to be accepted, and they see themselves as members of home regions to which they have no intention of returning [13]. [77] discusses the ceiling effect in public schools and the counter-school culture in private migrant schools as adaptations to external circumstances of institutional discrimination against migrants. The two mechanisms underpin the perpetuation of the class system and failure to facilitate upward mobility for migrant children in China.

School segmentation, rather than school enrollment, has emerged as the most important issue for migrant children in the central government's efforts to enroll them in urban schools. Migrant children are not fully incorporated into the urban education system, but are channeled into segregated spaces and segmented paths. In Shanghai, for example, in 2007-2009, the government managed to include 70 percent of migrant children in urban schools; however, many were in so-called "authorized migrant schools". These migrant schools are for migrant children only and are located mainly in peripheral districts [33] [35]. And although the migrant children who are enrolled in urban public schools are in the same schools as urban children, they are segregated in separate classes. In extreme cases, they are taught in separate spaces and have limited access to school facilities within the same school [28] [35]. Since the migrant children are not within the same system as the local children, it is unlikely likely that they will be integrated into the city.

Studies on school segregation of immigrant and minority children in the US are relevant to studies on Chinese migrant children. The theoretical framework and useful body of literature has developed around the theory of "segmented assimilation" [78]-[80] and its impact on children's development and academic achievement [81]. [72] and [35] raise the issue of segmented assimilation or segmented incorporation among the migrant children in China in Beijing and Shanghai, respectively. Based on qualitative interviews, [35] reviews barriers to the institutional integration of migrant children, such as spatial segregation, administrative barriers, quota of migrant children to be enrolled in urban schools; and barriers to the cultural integration of migrant children, such as social segregation, social discrimination and cultural differences. [35] concludes that systematic exclusion has given way to more subtle forms of institutional segmentation, which perpetuate cultural prejudice and reinforce group boundaries. In a study of the assimilation process of Chinese migrant children in urban cities, [72] finds that the strong institutional barriers against the rural population have deliberately limited Chinese migrant children from achieving the upward mobility and assimilation achieved by immigrant children in the US.

Again, many studies find that migrant children in public schools have integrated much better than those in migrant schools or public schools only for migrant children. [72] reports considerably improved academic performance and psychological well-being among migrant children in urban schools over time; however, migrant-school children lag well behind their cohort in public schools, and their feelings of loneliness and isolation do not completely fade. [82] conducts structural equation modeling (multiple-group analysis) to examine the dynamic relationships between the urban adaptation and social identity of migrant children within different types of school settings over time. They find that migrant children in public schools identity more with the host culture and make better progress in sociocultural adaptation, while those in migrant schools identify much more strongly with their place of origin and identify only weakly with the host culture.

Migrant children's adaptation process and the factors involved in that process are important for studies on migrant children’s social integration. [83] discusses multiple factors that affect the social integration of migrant 
children: factors related to the current hukou registration system; family factors, such as parental education and parental interaction with children; social factors, such as the role of school and community; and individual personality and psychological characteristics. However, they fail to discuss how these factors intertwine to affect each other. Future research should focus on understanding the multiple factors and their dynamic roles in the process of migrant children's social integration. Rather than simply exploring the average pattern of all migrant children's adaptation to the city, studies can examine the social adaptation of specific groups of migrant children living in different circumstances. Western studies examine the negative effects of migration on children's schooling due to the loss of social capital in school, the neighborhood, and the community of origin [84]-[86]. However, the literature on Chinese migrant children has not taken such factors into consideration.

\section{Indirect Social Consequences: Inequality and Poverty}

\subsection{Migrant Children's Educational Attainment and Education Inequality}

Despite its rapid economic growth, China has never managed to reduce its rural-urban divide with its reforms and marketization of the economy [87]. The ratio of urban to rural household income per capita was estimated to be around three in 2013 [5], and the CHIP survey found it to be 4.1 in 2007 [16]. The huge gap between urban and rural education is embedded in the disparity in educational investment [25], children's educational attainment [87]-[91], school quality [17] and the returns to the education [15] [92]. The local selective adaptation of central educational policy led to even more diverse conditions of compulsory education for migrant children across the nation [30].

While the issues of migrant children's educational attainment attract a lot of attention among scholars, education inequality has unavoidably emerged as the most important driving force behind these issues. Education inequality in China is based on two factors: residential location (urban vs. rural) and hukou entitlements.

Before the 1980s, basic education was expanded rather equally across the whole country to address the educational deficit and to serve China's growth and economic development in the early years. Since the economic reform, educational opportunities and public funding for the population of rural China has rapidly eroded. Fiscal decentralization strengthened educational development in urban areas over that in rural areas and, therefore, quickly enlarged the urban-rural gap in education provision [90]. Inadequate education funding and political preferences for urban development at the expense of rural development are the key issues affecting Chinese children's equal access to and quality of education. One of the most important aspects of rural-urban education inequality is the huge gap in quality [46]. However, the current research on rural schools' poor educational quality is mostly descriptive or case studies [93] [94]. The only attempts to quantitatively measure educational quality are based on children's academic scores [33] [69] [95].

Another branch of the literature examines hukou-based rural-urban educational inequality [46] [68] [96]. [96] employs endogenous switching regression models to demonstrate a causal impact of hukou on educational attainment. He finds that people with rural hukous are substantially disadvantaged in the number of years of education they can attain and that this disparity is consistent over time. On the other hand, [68] indicate that, after controlling for personal characteristics, migrant children's school performance is significantly lower than that of their urban counterparts. [97] estimates the value of an urban hukou to rural individuals and argues that the hukou system is major contributing factor in rural-urban inequality.

Some researchers also indicate that the rural-urban gap has grown larger in the transition from junior high to senior high school [98] [99]. The competition and selection are even more severe in the transition to senior high school than to college, as the expansion of senior high school education has lagged significantly behind the aggressive expansion of higher education since 1999 [100] [101]. The increased opportunities for higher education have been taken largely by students from urban areas, particularly from large cities [91]. [102] constructs school transition models and finds that hukou status plays important role in determining the likelihood of transition to junior high and academic senior high schools. Based on Sen's capability approach [103] to higher education, [102] examines the urban-rural disparity in education quality, uneven regional development of higher education, and regional disparities in admission to higher education. [102] concludes that the fundamentally flawed mechanism and socially constructed factors, such as family background, have denied migrant children fair competition in higher education admission.

The rural-urban inequality in education in China contributes not only to low educational attainment, but also to lower returns to education among the rural population [97]. [104] argues that the poor's low quality of educa- 
tion and inferior economic opportunities contribute to lower returns to education for the poor. [105] finds a significant gap in returns to education among people with different hukou statuses, and they conclude that this gap is higher between the urban and rural populations with less education.

The limitation in the current literature on educational inequality is in its small effort to explore the mechanisms that have transferred the urban-rural and regional educational inequality to the current hukou-based inequity between migrant and urban children. The possible mechanisms behind the hukou-based educational inequality are threefold. First, the urban-rural inequality of education quality is directly transferred by migration; both [27] and [31] report poor learning habits developed by migrant children who have been educated in rural areas. Second, migrant children are generally denied entrance to higher-quality urban schools. Even if enrolled in schools in cities, migrant children generally attend schools that are intended for migrant children or lowerquality public schools [35]. Third, migrant children do not have access to the entrance exam for higher education in urban cities, a situation that has largely dampened their enthusiasm for continuing study. Thus, rural-urban education inequality cannot be mitigated by rural children migrating to urban cities. The mechanisms behind hukou-based educational inequality are important topics for future studies.

\subsection{Migrant Children's Educational Attainment and Poverty}

Although many studies investigate the actual role of migration in alleviating poverty and subsidizing household income in rural areas [106], relatively few have attempted to study the role of the current educational system in alleviating poverty among migrants and the rural population.

The literature that discusses poverty issues for migrants rarely takes education into account [107]-[109]. Most studies on poverty and migrant children's educational attainment discuss the adverse effect of poverty on lower educational attainment, the high school dropout rate and poor academic performance [17] [110]. Other studies examine the disadvantaged social background of poor migrant families, such as the low involvement of migrant parents in their children's schooling [38] and the poor home environment for studying [31]. These studies discuss poverty as the cause of low educational attainment among migrant children.

However, very few studies attempt to examine the opposite causal relationship between education and poverty. Human capital theory identifies education as important capital to facilitate higher productivity and to benefit educated people [111]. One of the main incentives for rural-urban migrants is to remove the rural-urban institutional segmentation and barriers, with an effort to reduce rural-urban inequality. Even though migrants are better paid than their rural counterparts, they remain among the low-income population in cities due to their low education level. For migrant children who move to cities with their parents, education can play key role in the persistence of, or the potential escape from, the low-income equilibrium.

[104] views the relationships involving education, income and poverty as forming an inter-related system. The adverse effect of poverty on both the quantity and quality of education and the important role of education in helping raise households out of poverty are intertwined and mutually reinforced. The authors claim that without exogenous interventions, the poverty trap will be self-perpetuating; therefore, they call for policy interventions and institutional reform that will engineer an escape from the poverty trap. However, the education-poverty trap, as discussed by [104], is based on a rural setting and has not considered migrant children and hukou-based institutional constraints on their educational attainment in urban areas.

\section{Quantitative Data and Quantitative Research Methods}

\subsection{Quantitative Data}

Due to the easy availability of census data on children's education status, census data have been widely used to study migrant children's education situation in urban cities [2] [62] [63] [90] [91]. China has, so far, conducted six censuses (1953, 1964, 1982, 1990, 2000, 2010). Furthermore, a one percent population survey was first conducted in 1987, as well as every five years after each census since then. The advantage of the census and the one percent population survey is that they provide a good representation of the whole population. The limitation of census data is that the data contain rather limited information about migrant children's educational attainment. Therefore, census data have been used mainly to investigate the urban-rural gap in school enrollment, as well as families' demographic and socioeconomic factors that affect migrant children's school enrollment.

Several large-scale surveys in various years covering different geographic areas are also available for study- 
ing migrant children’s education. RUMiC (Longitudinal Survey on Rural-Urban Migration in China) [112] was conducted in 2008-2009, interviewing 8000 rural households in nine provinces, 5000 urban households in nineteen cities and 5000 migrant households in fifteen cities. The survey was purposely designed to differentiate among urban families, rural families, and rural-urban migrant families. The research topics include migrant children's education, health and the extent to which they assimilate into city communities [68] [113].

CFPS (China Family Panel Survey) is a nationally representative longitudinal survey launched in 2010 by Peking University. To date, CFPS has been conducted in four waves: 2010, 2011, 2012 and 2014 [114]. The survey team interviewed 16,000 households in 25 provinces. Children's personality, mental and physical health, learning habits and daily behaviors were followed and measured over certain periods. CFPS provided unified math, language and psychological tests to measure children's educational performance and psychological wellbeing [67] [115].

CEPS (China Education Panel Survey) is a national representative longitudinal survey, including both local children and migrant children in urban areas. The baseline survey, which was conducted in the 2013-14 academic year, interviewed around 20,000 grade 7 and grade 9 students and their parents about the children's educational situation. CEPS aims to explore the linkages between individuals' educational outcomes and the multiple contexts of families, school processes, communities and social structures, as well as the effects of educational outcomes during the course of people's lives. A follow-up survey was completed for the 2014-15 academic year.

NSTMCC (National Survey of Temporary Migrant Children in China) interviewed 6343 temporary migrant households in 2002-2003 via the national statistics bureaus in nine cities located in the eastern, central, and western parts of China [64] [65]. The main objective of the survey was to gain a comprehensive understanding of migrant children with respect to living environment, community services, education, access to health care, and protection of children's rights.

Several other large-scale surveys are available for studying left-behind children and migrant children, such as CHNS (China Health and Nutrition Survey), GSCF (Gansu Survey of Children and Families), CGSS (China General Social Survey), BMCCES (Beijing Compulsory Education Survey, 2005), and CHIP (Chinese Household Income Project).

\subsection{Quantitative Research Methods}

Families' socio-economic backgrounds greatly affect students' academic achievement [116] [117]. The correlation between socioeconomic status and academic achievement has large variance, moderated by unit, source, range of socioeconomic status variables and the type of measures [118]. The critical issue is, therefore, the difference between migrant children's socio-economic background and that of both non-migrant children in their place of origin and urban children in the destination areas. A direct comparison of the academic performance of these groups can reach rather misleading conclusion regarding the effect of migration on migrant children's education [119].

Except for a few studies that used purely descriptive methods [65] [90] [119], most studies based on quantitative data are built on quantitative analysis by controlling for families' socioeconomic characteristics and other relevant factors [33] [68] [69] [94]. The early quantitative studies focusing on migrant children's school enrollment apply mainly logistic regression [11] [63] [64] [101] [120].

More recent studies criticize the use of school enrollment as the main measure because it ignores the issue of educational quality, and children's academic scores have gained popularity in evaluating children's school performance. Most of such quantitative studies apply multivariate regression analysis, controlled by various measures of socioeconomic background. Family background, such as parents' socioeconomic status and household income, is the most commonly controlled factor. In addition, various studies use other controlling factors, such as students' academic history [33]; nutrition; parenting style [68]; social capital based on family relations, such as parental expectations and involvement [95]; and indicators of school quality, such as school resources and teacher characteristics [69]. Some studies also carefully consider possible self-selection biases by using fixedeffect estimation and Instrument Variables [33] [64] [69] [106]. In order to rule out the selectivity effect of hukou assignment based on education, [96] employs endogenous switching regression models to demonstrate a causal impact of hukou on educational attainment.

Other analytical methods, such as the propensity score matching method, areused to estimate the average 
treatment effects of migration on the school performance of migrant and left-behind children [67]. Survival analysis has also been applied in exploring the effects of grandparents on children's schooling in rural areas [121], but, so far, it has not been used on migrant children's school performance.

Finally, since policy implementations in migrant children's schooling in urban areas vary greatly, the study of one specific city or community might not be directly applicable to other regions. The conclusions of different studies need careful interpretation. It is also important to take into consideration the endogenous correlations between families' migrant status and family characteristics and school types.

\section{Limitations of Current Studies and Future Research}

This review identifies the limitations of the current research on migrant children's education and, therefore, suggests several areas to be explored in future research work.

The studies on local barriers to migrant children's education have, so far, been rather restricted to certain areas or cities and have not been systematic or comprehensive. Various studies refer to different local regulations on fees and administrative rules published by different local governments at various times. Although researchers are aware of the variety of local education regulations aimed at migrant children, as yet, no one has attempted a systematic comparison and mapping of these regulations on migrant children's access to public education in cities.

Relatively few Chinese studies on migrant children's education consider the negative effects of migration on children's schooling due to the loss of social capital in school, the neighborhood, and the community of origin, which western studies have looked at in some detail. Some families migrate frequently due to the need to work. Studies on children from such migrant families should take these factors into consideration.

The recent literature has focused mainly on migrant children's access to compulsory education. Although some studies discuss migrant children's ineligibility to take the entrance exam for higher education and the obstacles they face in pursuing higher education, a few attempt to explore the potential social consequences of such restrictions on further expanding the existing rural-urban inequality in attaining a higher educational. Furthermore, little effort has been made to explore the effects of such constitutional obstacles to migrant children's long-term educational development.

In the studies on migrant children's adaptation process, different factors have played important roles. However, current studies fail to discuss them as intertwined factors that can affect and reinforce each other. For migrant children in different types of schools, it is important to consider the multi-correlation between the social background of migrant families, the school type and the migrant children's school performance. There is apparently self-selection of migrant children with a poor family background into migrant schools. However, relatively few studies have taken the endogenous nature of the migration decision into consideration. Future research can be focused on understanding the multiple factors and their dynamic roles in the process of migrant children's social integration. Rather than simply exploring the average pattern of all migrant children's adaptation to the city, it is useful to target the social adaptation of specific groups of migrant children living in different circumstances.

One important aspect of studies on education in equality is the huge gap in the education quality. However, education quality is a difficult concept to measure, and the literature on it is mostly descriptive. The only attempt to quantitatively measure migrant children's school performance has been based on academic scores. Furthermore, there has been very little effort to explore the institutional mechanisms that transfer the urban-rural or regional educational inequality to hukou-based educational inequity in the cities. The quantitative measurement of education quality and institutional mechanisms behind hukou-based educational inequality are important topics for future studies.

The research on the correlation between education and poverty has not received much attention. The current studies focus on the role of migration in alleviating poverty or the adverse effect of poverty and poor migrant families' disadvantaged social background on migrant children's educational attainment. However, the key role of education in migrant children's long-term development has still not been explored adequately. Without a proper education, migrant children will be stuck in the same poverty trap as their parents. Migrants move to the cities in a hope of escaping the poverty trap in their rural place of origin and providing their children with a better future; however, institutional barriers based on the hukou system have only strengthened the educationpoverty trap in a new setting. Therefore, it is important to view education and poverty as an intertwined system, in which both aspects work together to affect the future of migrant children. 


\section{References}

[1] Chen, G. and Yang, J. (2010) Access to Compulsory Education by Rural Migrants' Children in Urban China: A Case Study from Nine Cities. Journal of Education for International Development, 4, No. 3.

[2] Wu, W. and Wang, G. (2014) Together but Unequal: Citizenship Rights for Migrants and Locals in Urban China. Urban Affairs Review, 50, 781-805. http://dx.doi.org/10.1177/1078087413518172

[3] Cheng, T. and Selden, M. (1994) The Origins and Social Consequences of China’s Hukou System. The China Quarterly, 139, 644-668. http://dx.doi.org/10.1017/S0305741000043083

[4] Chan, K.W. and Zhang, L. (1999) The Hukou System and Rural-Urban Migration in China: Processes and Changes. The China Quarterly, 160, 818-855. http://dx.doi.org/10.1017/S0305741000001351

[5] National Bureau of Statistics of China (2014) Chinese Statistical Yearbook. National Bureau of Statistics of China, Beijing.

[6] Hua, Y. (1994) Migrant Children’s School Enrollment. Tianjing Education, No. 6. (In Chinese)

[7] Long, T. (1994) Drifting Flowers-Memorandum of Migrant Children’s Education. Society, No. 8. (In Chinese)

[8] Li, J. (1995) Where Should the Migrant Children Go To School—Investigation of the Education of Migrant Children. China Education Daily. (In Chinese)

[9] Duan, C. and Liang, H. (2005) Research on the Compulsory Education of Migrant Children. Population and Economics, No. 148, 11-17. (In Chinese)

[10] Hong, Z., Zhiyong, Q. and Qiulin, Z. (2005) Development and Need of Migrant Children in nine Chinese Cities. The Youth Research, No. 2, 1-7. (In Chinese)

[11] Guo, F. (2002) School Attendance of Migrant Children in Beijing, China: A Multivariate Analysis. Asian and Pacific Migration Journal, 11, 357-374. http://dx.doi.org/10.1177/011719680201100304

[12] Zhu, M. (2001) The Education Problems of Migrant Children in Shanghai. Child Welfare, 80, 563-569.

[13] Kwong, J. (2004) Educating Migrant Children: Negotiations between the State and Civil Society. The China Quarterly, 180, 1073-1088. http://dx.doi.org/10.1017/S030574100400075X

[14] Yan, F. (2005) Education Problems with Urban Migratory Children in China. Journal of Sociology and Social Welfare, 32, 3-10.

[15] Wang, X., Piesse, J. and Weaver, N. (2010) Mind the Gaps: A Political Economy of the Multiple Dimensions of China’s Rural-Urban Divide. Asian-Pacific Economic Literature, 27, 52-67. http://dx.doi.org/10.1111/apel.12026

[16] Knight, J. (2014) Inequality in China: An Overview. World Bank Research Observer, 29, 1-19. http://dx.doi.org/10.1093/wbro/lkt006

[17] Brown, P.H. and Park, A. (2002) Education and Poverty in Rural China. Economics of Education Review, 21, 523-541. http://dx.doi.org/10.1016/S0272-7757(01)00040-1

[18] Chan, K.W. (2010) The Household Registration System and Migrant Labor in China: Note on a Debate. Population and Development Review, 36, 357-364. http://dx.doi.org/10.1111/j.1728-4457.2010.00333.x

[19] Chan, K.W. and Buckingham, W. (2008) Is China Abolishing the Hukou System. The China Quarterly, 195, 582-606.

[20] Fan, C. (2008) China on the Move. Routledge Taylor \& Francis Group, London.

[21] Su, M. and Zhao, Q. (2004) China’s Fiscal Decentralization Reform. International Symposium on Fiscal Decentralization in Asia Revisited, Tokyo, 20-21 February 2004.

[22] Demery, L. (1996) Gender and Public Social Spending: Disaggregating Benefit Incidence. The World Bank.

[23] Tsang, M.C. (1996) Financial Reform of Basic Education in China. Economics of Education Review, 15, 423-444. http://dx.doi.org/10.1016/S0272-7757(96)00016-7

[24] Li, W., Park, A. and Wang, S. (2002) School Equity in Rural China. The Association of Asian Studies, Washington DC.

[25] Fu, T.M. (2005) Unequal Primary Education Opportunities in Rural and Urban China. China Perspectives, 30-36. http://dx.doi.org/10.3406/perch.2005.3316

[26] Tsang, M.C. (2005) Resource Utilization and Disparities in Compulsory Education in China. China Review, 5, 1-31.

[27] Guo, J. (2013) Financing Migrant Child Education. In: Besharov, D. and Baehler, K., Eds., Chinese Social Policy in a Time of Transition, Oxford University Press, New York, 142-159. http://dx.doi.org/10.1093/acprof:oso/9780199990313.003.0008

[28] Li, N. and Placier, P.L. (2015) The Impact of Changes in Chinese Government Policy on Rural-Urban Migrant Children's Schooling. Asian Social Science, 11, 31-41. http://dx.doi.org/10.5539/ass.v11n18p31 
[29] Chinese National Education Committee (1996) The Trial Measure of School Education for School-Age Children among Urban Floating Population. (In Chinese) http://www.hbe.gov.cn/content.php?id=1357

[30] Wang, L. (2015) Local Adaptation of Central Policies: The Policymaking and Implementation of Compulsory Education for Migrant Children in China. Asia Pacific Education Review, 1-15.

[31] Li, X., Zhang, L., Fang, X., Stanton, B., Xiong, Q., Lin, D., et al. (2010) Schooling of Migrant Children in China: Perspectives of School Teachers. Vulnerable Children and Youth Studies, 5, 79-87. http://dx.doi.org/10.1080/17450120903193931

[32] Goodburn, C. (2009) Learning from Migrant Children: A Case Study of the Schooling of Rural Migrant Children in Beijing. International Journal of Educational Development, 29, 495-504. http://dx.doi.org/10.1016/j.ijedudev.2009.04.005

[33] Chen, Y. and Feng, S. (2013) Access to Public Schools and the Education of Migrant Children in China. China Economic Review, 26, 75-88. http://dx.doi.org/10.1016/j.chieco.2013.04.007

[34] Goodburn, C. (2014) Educating Migrant Children: The Effects of Rural-Urban Migration on Access to Primary Education. In: Guo, S. and Guo, Y., Eds., Spotlight on China: Changes in Education under China's Market Economy, Sense Publishers.

https://kclpure.kcl.ac.uk/portal/files/12725675/Charlotte Goodburn chapter Educating Migrant Children revised.pdf

[35] Lan, P.-C. (2014) Segmented Incorporation: The Second Generation of Rural Migrants in Shanghai. The China Quarterly, 217, 243-265. http://dx.doi.org/10.1017/S030574101300146X

[36] Koo, A. (2012) Is There Any Chance to Get Ahead? Education Aspirations and Expectations of Migrant Families in China. British Journal of Sociology of Education, 33, 547-564. http://dx.doi.org/10.1080/01425692.2012.678755

[37] Guo, J. (2009) Financing of Education: A Missing Dimension of Migrant Child Education Policy in China. Association for Public Policy Analysis \& Management (APPAM) Special International Conference, Singapore, 8 January 2009, 1-17. http://umdcipe.org/conferences/policy_exchanges/conf_papers/Papers/1451.pdf

[38] Wang, L. and Holland, T. (2011) In Search of Educational Equity for the Migrant Children of Shanghai. Comparative Education, 47, 471-487. http://dx.doi.org/10.1080/03050068.2011.559701

[39] China News (2015) Challenges for Migrant Children to School: Migrant Children in Beijing Need 28 Certificates to Apply for School. http://www.chinanews.com/gn/2015/06-15/7343719.shtml

[40] Dong, J. (2010) Neo-Liberalism and the Evolvement of China’s Education Policies on Migrant Children’s Schooling. Journal for Critical Education Policy Studies, 8, 137-160.

[41] Zhang, L. (2013) Citizenship in Urban China: The Case of the Points Systems. Day-Long Conference on China's Domestic Challenges, Fudan-UC Center on Contemporary China \& 21st Century China Program, Shanghai. http://fudan-uc.ucsd.edu/ files/03252013 paper zhang.pdf

[42] Weng, F. (2013) Why Recent Hukou Reform Is Insufficient in Addressing Urban-Rural Disparities. The Journal of Political Studies, 1, 1-11.

[43] People’s Daily (2013) Point System of Residence Permit to Be Implemented in Shanghai. http://politics.people.com.cn/n/2013/0620/c1001-21902572.html

[44] Shanghai Government (2013) Regulations of Shanghai Residence Permit. http://www.shanghai.gov.cn/nw2/nw2314/nw2319/nw2404/nw31379/nw31380/u26aw36282.html

[45] Wu, K. and Li, Z. (2010) Developmentist Government and Urban Hukou Threshold: Rethinking Hukou System Reform (发展主义政府与城市落户门槛: 关于户籍制度改革的反思). Sociological Studies, 25, 58-85.

[46] Montgomery, J.L. (2012) The Inheritance of Inequality: Hukou and Related Barriers to Compulsory Education for China’s Migrant Children. Pacific Rim Law \& Policy Journal, 21, 591-622. http://digital.law.washington.edu/dspace-law/bitstream/handle/1773.1/1165/21PRPLJ591.pdf?sequence=1

[47] Baidu. (2009) Report on Migrant Children School in Beijing. (In Chinese) http://www.douban.com/group/topic/6967756/

[48] Xinhua News (2006) Thirty Schools Shut Down, Over 10,000 Migrant Children Out of School. (In Chinese) http://news.xinhuanet.com/society/2006-08/08/content_4932299.htm

[49] Asia News (2006) Three Hundred Migrant Children School to Be Shut down in Guangdong Province. (In Chinese)

[50] Du, Z. (2006) Who Abandon Migrant Schools? Law and Life, 17, 2-24.

[51] Tao, H. and Yang, D. (2007) Problems and Stratigies Concerning the Education of Migrant Children in Beijing. Jiangxi Educational Research, 1, 61-63.

[52] Zhao, S., Chen, X. and Wang, L. (2015) Maternal Parenting and Social, School, and Psychological Adjustment of Mi- 
grant Children in Urban China. International Journal of Behavioral Development, 39, 541-551. http://dx.doi.org/10.1177/0165025415576815

[53] Shanghai Government (2009) 2008 Compulsory Education Status of Migrant Children in Shanghai. (In Chinese) http://www.shanghai.gov.cn/shanghai/node2314/node22512/node22516/u8ai23513.html

[54] Burkhoff, A. (2015) “One Exam Determines One’s Life”: The 2014 Reforms to the Chinese National College Entrance Exam. Fordham International Law Journal, 38, 1473-1510.

[55] Xinhua News (2010) Long-Term Education Reform and Development Plan (2010-2020). http://www.gov.cn/jrzg/2010-07/29/content 1667143.htm

[56] People Daily (2015) The NDRC Report: 80,000 Migrant Children Took College Entrance Examination in Cities This Year. http://edu.people.com.cn/n/2015/0827/c367001-27525217.html

[57] SAES (2011) Policy on Migrant Children’s College entrance Examination-Research and Exploration in Shanghai. Education Development Research, 3. (In Chinese)

[58] Ministry of Education (2015) Regulation for College Entrance Exam. http://edu.people.com.cn/n/2015/0215/c1053-26571363.html

[59] Koo, A., Ming, H. and Tsang, B. (2014) The Doubly Disadvantaged: How Return Migrant Students Fail to Access and Deploy Capitals for Academic Success in Rural Schools. Sociology, 48, 795-811. http://dx.doi.org/10.1177/0038038513512729

[60] Brauw, A.D. and Giles, J. (2008) Migrant Opportunity and the Educational Attainment of Youth in Rural China. The World Bank, Development Research Group, Policy Research Working Paper.

[61] Xinhua News (2004) Millions of Migrant Children Can’t Afford Education. http://www.china.org.cn/english/culture/87613.htm

[62] Wu, X. and Zhang, Z. (2013) Population Migration and Children’s School Enrollments in China, 1990-2005. PSC Research Report No. 13-794.

[63] Liang, Z. and Chen, Y.P. (2005) The Educational Consequences of Migration for Children in China. Social Science Research, 36, 28-47. http://dx.doi.org/10.1016/j.ssresearch.2005.09.003

[64] Lu, Y. (2007) Educational Status of Temporary Migrant Children in China: Determinants and Regional Variations. Asian and Pacific Migration Journal, 16, 29-55. http://dx.doi.org/10.1177/011719680701600102

[65] Liang, Z., Guo, L. and Duan, C.C. (2008) Migration and the Well-Being of Children in China. The Yale-China Health Journal, 5, 25-46.

[66] Hu, Y. and Szente, J. (2010) Education of Young Chinese Migrant Children: Challenges and Prospects. Early Childhood Education Journal, 37, 477-482. http://dx.doi.org/10.1007/s10643-009-0362-8

[67] Xu, H. and Xie, Y. (2013) The Causal Effects of Rural-to-Urban Migration on Children's Well-Being in China. Institute for Social Research, Population Studies Center, University of Michigan, Ann Arbor.

[68] Zhang, D., Li, X. and Xue, J. (2015) Education Inequality between Rural and Urban Areas of the People's Republic of China, Migrants' Children Education, and Some Implications. Asian Development Review, 32, 196-224. http://dx.doi.org/10.1162/ADEV_a_00042

[69] Lai, F., Liu, C., Luo, R., Zhang, L., Ma, X., Bai, Y., et al. (2014) The Education of China’s Migrant Children: The Missing Link in China's Education System. International Journal of Educational Development, 37, 68-77. http://dx.doi.org/10.1016/j.ijedudev.2013.11.006

[70] Liu, T., Holmes, K. and Albright, J. (2015) Predictors of Mathematics Achievement of Migrant Children in Chinese Urban Schools: A Comparative Study. International Journal of Educational Development, 42, 35-42. http://dx.doi.org/10.1016/j.ijedudev.2015.03.001

[71] Wong, F.K., Chang, Y.L. and He, X.S. (2009) Correlates of Psychological Well-Being of Children of Migrant Workers in Shanghai, China. Social Psychiatry and Psychiatric Epidemiology, 44, 815-824. http://dx.doi.org/10.1007/s00127-009-0003-y

[72] Lu, Y. and Zhou, H. (2013) Academic Achievement and Loneliness of Migrant Children in China: School Segregation and Segmented Assimilation. Comparative Education Review, 57, 85-116. http://dx.doi.org/10.1086/667790

[73] Gao, Q., Li, H., Zou, H., Cross, W., Bian, R. and Liu, Y. (2015) The Mental Health of Children of Migrant Workers in Beijing: The Protective Role of Public School Attendance. Scandinavian Journal of Psychology, 56, 384-390. http://dx.doi.org/10.1111/sjop.12232

[74] Hu, H., Lu, S. and Huang, C.-C. (2014) The Psychological and Behavioral Outcomes of Migrant and Left-Behind Children in China. Children and Youth Services Review, 46, 1-10. http://dx.doi.org/10.1016/j.childyouth.2014.07.021

[75] Gao, M. (2013) The Physical and Psychological Mechanisms of Educational Inequality and Intervention Strategies: 
The Case of Migrant Workers' Children. Social Sciences in China, 34, 38-57. http://dx.doi.org/10.1080/02529203.2013.849090

[76] Wang, L. (2008) The Marginality of Migrant Children in the Urban Chinese Educational System. British Journal of Sociology of Education, 29, 691-703. http://dx.doi.org/10.1080/01425690802423361

[77] Xiong, Y. (2015) The Broken Ladder: Why Education Provides No Upward Mobility for Migrant Children in China. China Quarterly, 221, 161-184. http://dx.doi.org/10.1017/S0305741015000016

[78] Portes, A. and Zhou, M. (1993) The New Second Generation: Segmented Assimilation and its Variants. Annals of the American Academy of Political and Social Science, 530, 74-96. http://dx.doi.org/10.1177/0002716293530001006

[79] Portes, A., Fernandez-Kelly, P. and Haller, W. (2005) Segmented Assimilation on the Ground: the New Second Generation in Early Adulthood. Ethic \& Racial Studies, 28, 1000-1040. http://dx.doi.org/10.1080/01419870500224117

[80] Zhou, M. (1997) Segmented Assimilation: Issues, Controversies, and Recent Research on the New Second Generation. International Migration Review, 31, 975-1008. http://dx.doi.org/10.2307/2547421

[81] Rumberger, W. and Palardy, G.J. (2005) Does Segregation Still Matter? The Impact of Student Composition on Academic Achievement in High School. Teachers College Record, 107, 1999-2045.

[82] Yuan, X., Fang, X., Liu, Y., Hou, S. and Lin, X. (2013) Development of Urban Adaptation and Social Identity of Migrant Children in China: A Longitudinal Study. International Journal of Intercultural Relations, 37, 354-365. http://dx.doi.org/10.1016/j.ijintrel.2012.10.002

[83] Cheng, K. and Chen, X. (2014) The Analysis of Influencing Factors in Social Integration of Urban Migrant Children. Studies in Asian Social Science, 1, 1-19.

[84] Astone, N.M. and Mclanahan, S.S. (1994) Family Structure, Residential Mobility, and School Dropout: A Research Notes. Demography, 31, 575-584. http://dx.doi.org/10.2307/2061791

[85] Buchmann, C. and Hannum, E. (2001) Education and Stratification in Developing Country: A Review of Theories and Research. Annual Review of Sociology, 27, 77-102. http://dx.doi.org/10.1146/annurev.soc.27.1.77

[86] Pribesh, S. and Downey, D.B. (1999) Why Are Residential and School Moves Associated with Poor School Performance? Demography, 36, 521-534. http://dx.doi.org/10.2307/2648088

[87] Wang, X. and Piesse, J. (2008) Laobr Market Segregation and Integration in China: A Spatial and Sectoral Analysis, 1988-2002. KCL Department of Management Research Paper Series No. 51.

[88] Knight, J. and Song, L. (1999) The Rural-Urban Divide: Economic Disparities and Interactions in China. Oxford University Press, Oxford. http://dx.doi.org/10.1093/acprof:oso/9780198293309.001.0001

[89] Knight, J., Li, S. and Song, L. (2006) The Rural-Urban Divide and the Evolution of Political Economy in China. In: Griffin, K.B., Ed., Human Development in the Era of Globalization, Edward Elgar, Northampton, 44-63.

[90] Hannum, E. (1999) Political Change and the Urban-Rural Gap in Basic Education in China, 1949-1990. Comparative Education Review, 43, 193-211. http://dx.doi.org/10.1086/447554

[91] Wu, X. (2010) Changes in Educational Inequality in China, 1990-2005. Evidence from the Population Cencus Data. http://works.bepress.com/xiaogang wu/15/

[92] Appleton, S., Knight, J., Song, L. and Xia, Q. (2004) Contrasting Paradigms: Segmentation and Competitiveness in the Formation of the Chinese Labour Market. Journal of Chinese Economic and Business Studies, 2, 185-205. http://dx.doi.org/10.1080/1476528042000276141

[93] Chuang, C. and Mason, M. (2012) Why Do Primary School Students Drop out in Poor, Rural China? A Portrait Sketched in a Remote Mountain Village. International Journal of Educational Development, 32, 537-545. http://dx.doi.org/10.1016/j.ijedudev.2012.02.012

[94] Wang, D. (2003) China’s Rural Compulsory Education: Current Situation, Problems and Policy Alternatives. WP 36, Institute of Population and Labor Economics, Chinese Academy of Social Sciences, Beijing.

[95] Guo, J. (2011) Family and Parent Correlates of Educational Achievement: Migrant Children in China. Asian Social Work and Policy Review, 5, 123-137. http://dx.doi.org/10.1111/j.1753-1411.2011.00054.x

[96] Wu, X. (2011) The Household Registration System and Rural-Urban Educational Inequality in Contemporary China. Population Studies Center Report 11-735, Florence, Italy.

[97] Liu, Z. (2005) Institution and Inequality: The Hukou System in China. Journal of Comparative Economics, 33, 133157. http://dx.doi.org/10.1016/j.jce.2004.11.001

[98] Connelly, R. and Zheng, Z. (2007) Enrollment and Graduation Patterns as China’s Reforms Deepen, 1990-2000. In: Hannum, E. and Park, A., Eds., Education and Reform in China, Routledge, London, 81-92.

[99] Wu, X. (2007) Family Resources and Educational Stratification: the Case of Hong Kong, 1981-2001. Social Transformations in Chinese Societies, 3, 1-37. 
[100] Lin, J. and Zhang, Y. (2006) Educational Expansion and Shortages in Secondary Schools in China: The Bottle Neck Syndrome. Journal of Contemporary China, 15, 255-274. http://dx.doi.org/10.1080/10670560500534889

[101] Loyalka, P., Chu, J., Wei, J., Johnson, N., Reniker, J. and Rozelle, S. (2014) Inequalities in the Pathway to College in China: When Do Students from Poor Areas Fall Behind? http://reap.fsi.stanford.edu/publication/277-inequalities-pathway-college-china-when-do-students-poor-areas-fall-behin $\underline{\mathrm{d}}$

[102] Wang, L. (2011) Social Exclusion and Inequality in Higher Education in China: A Capability Perspective. International Journal of Educational Development, 31, 277-286. http://dx.doi.org/10.1016/j.ijedudev.2010.08.002

[103] Sen, A. (1985) Commodities and Capabilities. North-Holland, Amsterdam.

[104] Knight, J., Li, S. and Quheng, D. (2010) Education and the Poverty Trap in Rural China: Closing the Trap. Oxford Development Studies, 38, 1-24. http://dx.doi.org/10.1080/13600810903551595

[105] Fu, Q. and Ren, Q. (2010) Educational Inequality under China’s Rural-Urban Divide: The Hukou System and Return to Education. Environment and Planning A, 3, 592-610. http://dx.doi.org/10.1068/a42101

[106] Du, Y., Park, A. and Wang, S. (2005) Migration and Rural Poverty in China. Journal of Comparative Economics, 33, 688-709. http://dx.doi.org/10.1016/j.jce.2005.09.001

[107] Albert, P. and Wang, D. (2010) Migration and Urban Poverty and Inequality in China. China Economic Journal, 3, 4967. http://dx.doi.org/10.1080/17538963.2010.487351

[108] Hussain, A. (2003) Urban Poverty in China: Measurement, Patterns and Policies. International Labour Office, Geneva.

[109] Wang, D., Wu, Y. and Cai, F. (2004) Migration, Unemployment and Urban Labor Market Segregation in China's Economic Transition. The World Economy, 4.

[110] Knight, J., Shi, L. and Quheng, D. (2009) Education and the Poverty Trap in Rural China: Setting the Trap. Oxford Development Studies, 37, 311-332. http://dx.doi.org/10.1080/13600810903305232

[111] Becker, C. (1964) Human Capital: A Theoretical and Empirical Analysis, with Special Reference to Education. National Bureau of Economic Research, New York.

[112] Akgüç, M., Giulietti, C. and Zimmermann, K.F. (2014) The RUMiC Longitudinal Survey: Fostering Research on Labor Markets in China. IZA Journal of Labor \& Development, 3, 5. http://dx.doi.org/10.1186/2193-9020-3-5

[113] Meng, X. and Yamauchi, C. (2015) Children of Migrants: The Impact of Parental Migration on Their Children’s Education and Health Outcomes. Institute for the Study of Labor, Forschungsinstitut.

[114] Xie, Y. and Hu, J. (2014) An Introduction to the China Family Panel Studies (CFPS). Chinese Sociological Review, 47, 3-29.

[115] Ren, Q. and Treiman, D. (2013) The Consequences of Parental Labor Migration in China for Children’s Emotional Well-being. Institute for Social Research, Population Studies Center, University of Michigan, Ann Arbor.

[116] Caro, D.H. (2009) Socio-Economic Status and Academic Achievement Trajectories from Childhood to Adolescence. Canadian Journal of Education, 32, 558-590.

[117] Zhao, N., Valcke, M., Desoete, A. and Verhaeghe, J. (2012) The Quadratic Relationship between Socioeconomic Status and Learning Performance in China by Multilevel Analysis: Implications for Policies to Foster Education Equity. International Journal of Educational Development, 32, 412-422. http://dx.doi.org/10.1016/j.ijedudev.2011.08.004

[118] Sirin, S.R. (2005) Socioeconomic Status and Academic Achievement: A Meta-Analytic Review of Research. Review of Educational Research, 75, 417-453. http://dx.doi.org/10.3102/00346543075003417

[119] Xue, L. and Shi, T. (2001) Inequality in Chinese Education. Journal of Contemporary China, 10, 107-124. http://dx.doi.org/10.1080/10670560124330

[120] Jia, Z. and Tian, W. (2010) Loneliness of Left-behind Children: A Cross-Sectional Survey in a Sample of Rural China. Child: Care, Health and Development, 36, 812-817. http://dx.doi.org/10.1111/j.1365-2214.2010.01110.x

[121] Zeng, Z. and Xie, Y. (2014) The Effects of Grandparents on Children's Schooling: Evidence from Rural China. Demography, 51, 599-617. http://dx.doi.org/10.1007/s13524-013-0275-4 


\section{Submit or recommend next manuscript to SCIRP and we will provide best service for you:}

Accepting pre-submission inquiries through Email, Facebook, LinkedIn, Twitter, etc.

A wide selection of journals (inclusive of 9 subjects, more than 200 journals)

Providing 24-hour high-quality service

User-friendly online submission system

Fair and swift peer-review system

Efficient typesetting and proofreading procedure

Display of the result of downloads and visits, as well as the number of cited articles

Maximum dissemination of your research work

Submit your manuscript at: http://papersubmission.scirp.org/ 